\title{
Air Blast
}

National Cancer Institute

\section{Source}

National Cancer Institute. Air Blast. NCI Thesaurus. Code C82101.

A short burst of air. 